\title{
Correction: Prolactin mediates psychological stress-induced dysfunction of regulatory $T$ cells to facilitate intestinal inflammation
}

Wu W, Sun M, Zhang H, et al. Prolactin mediates psychological stress-induced dysfunction of regulatory T cells to facilitate intestinal inflammation. Gut 2014;66:1883-92. doi: 10.1136/ gutjnl-2013-306083.

The wrong C4 panel was included in figure 6. The correct figure 6 is below.

The figure legend remains the same.
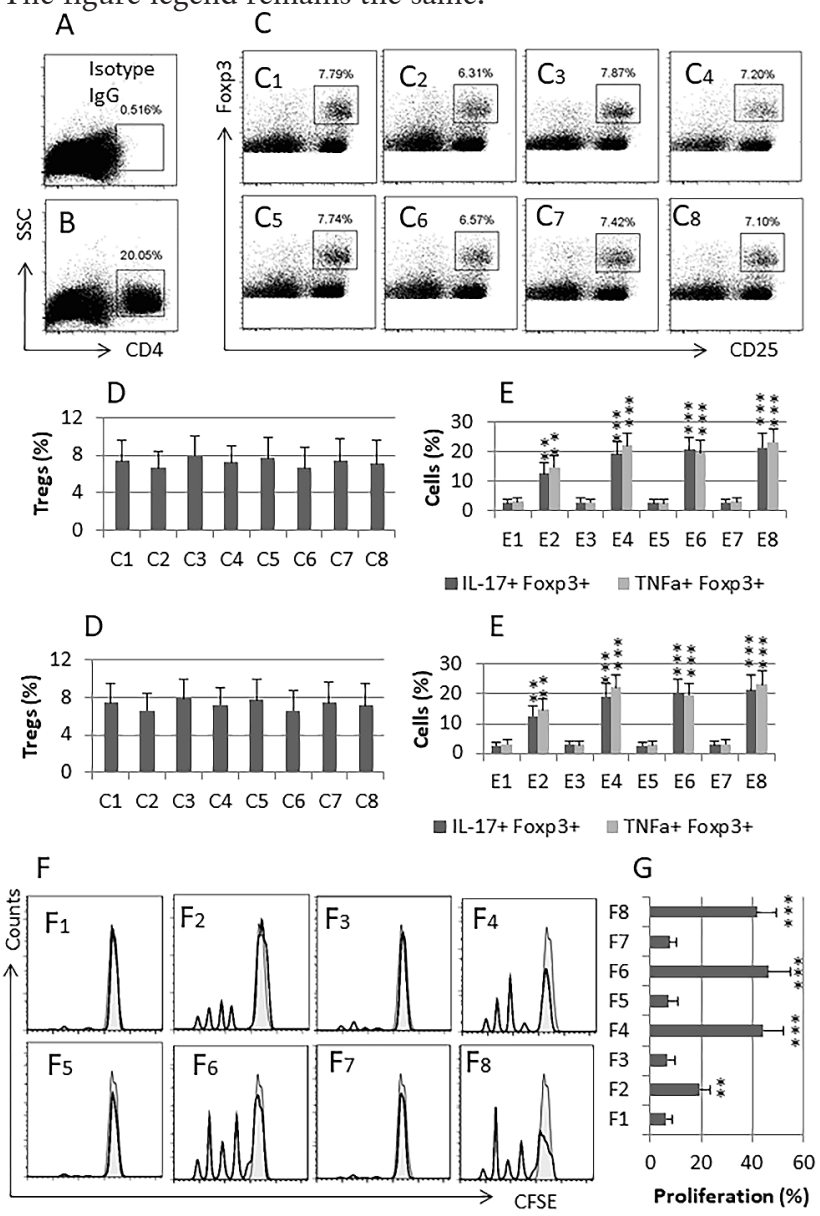

\section{(2) \\ OPEN ACCESS}

Open access This is an open access article distributed in accordance with the Creative Commons Attribution Non Commercial (CC BY-NC 4.0) license, which permits others to distribute, remix, adapt, build upon this work noncommercially, and license their derivative works on different terms, provided the original work is properly cited, appropriate credit is given, any changes made indicated, and the use is non-commercial. See: http://creativecommons.org/licenses/by-nc/ 4.0\%.

(C) Author(s) (or their employer(s)) 2020. Re-use permitted under CC BY-NC. No commercial re-use. See rights and permissions. Published by BMJ.

Gut 2020;69:e7. doi:10.1136/gutjnl-2013-306083corr1

(D) Check for updates 